\title{
Deformacje eksploatacyjne toru tramwajowego determinujące skrajnię budowli
}

\author{
W pracy przedstawiono deformacje toru tramwajowego powstajace $w$ wyniku eksploatacji a \\ majace wplyw na skrajnię budowli.
}

\section{Wstęp}

Praca jest wynikiem realizacji projektu badawczego wlasnego nr N509 035 31/2367 finansowanego przez Ministerstwo Nauki i Szkolnictwa Wyższego pt.: Metodyka wyznaczania kinematycznego zapotrzebowania przestrzeni oraz luzów bezpieczeństwa dla pojazdów tramwajowych celem ustalenia optymalnego zarysu pojazdu."

Celem opracowania jest wskazanie na czynniki wywołane deformacjami eksploatacyjnymi toru tramwajowego wpływającymi na skrajnię budowli.

Kontur koniecznej przestrzeni niezabudowanej (skrajni budowli) powstaje $\mathrm{z}$ zarysu odniesienia skrajni kinematycznej [1] w drodze poszerzania tego zarysu o amplitudy (czynniki) ruchów pasożytniczych (szkodliwych) pojazdu wywołanych deformacjami eksploatacyjnymi toru.

$\mathrm{Na}$ torach w miarę upływu czasu ich eksploatowania zaczynają się pojawiać następujące deformacje mające wpływ na ruchy pasożytnicze pojazdu $[2,3]$ :

- zygzakowatość toru (terminologia anglojęzyczna „track stagger”),

- przesunięcie się toru w poprzek (,transversal track dislocation"),

- nierównomierne zużycie boków główek szyn (,uneven wear of the rail sides"),

- zapadnięcie pionowe toru (,,vertical track subsidence"),

- zużycie główek szyn (,wear of the rail tops"),

- wichrowatość toru (,track twist”).

Rozpatrzymy po kolei wszystkie te deformacje.

\section{Zygzakowatość toru}

2.1. Dopuszczalna wielkość zygzakowatości toru Według [2,3] dopuszcza się następującą zygzakowatość toru (rys.1).

Zatem amplituda zygzakowatości wynosi

$$
\mathrm{e}_{\text {zygz }}=\frac{50}{2}=25 \mathrm{~mm}=0,025 \mathrm{~m}
$$

a ćwierć długości fali zygzakowatości wynosi co najmniej

$$
A_{\text {zygz }}=\frac{10000}{2}=5000 \mathrm{~mm}=5 \mathrm{~m} \text {. }
$$

Kąt zygzakowatości wynosi

$$
\alpha_{\text {zygz }}=\frac{e_{\text {zygz }}}{A_{\text {zygz }}}=\frac{0,025}{5}=0,005 .
$$

2.2.Ustawienie statyczne pojazdu w zygzaku toru, gdy zestawy kołowe zajmują środkowe położenie w torze (rys. 2).

Odbieganie punktu A pojazdu od osi toru idealnego wyniesie

$$
\mathrm{e}_{\mathrm{A}}=\mathrm{e}_{\mathrm{zygz}}-\frac{\mathrm{p}}{2} \cdot \alpha_{\mathrm{zygz}}=\left(1-\frac{\mathrm{p}}{2 \mathrm{~A}_{\mathrm{zygz}}}\right) \cdot \mathrm{e}_{\mathrm{zygz}} \cdot
$$

Odbieganie punktu $\mathrm{C}$ pojazdu od osi toru idealnego wyniesie

$$
\mathrm{e}_{\mathrm{C}}=\mathrm{e}_{\mathrm{A}}+\mathrm{l}_{\mathrm{pr}} \cdot \alpha_{\mathrm{zygz}}=\left(1+\frac{21_{\mathrm{pr}}-\mathrm{p}}{2 \mathrm{~A}_{\mathrm{zygz}}}\right) \cdot \mathrm{e}_{\mathrm{zygz}}
$$

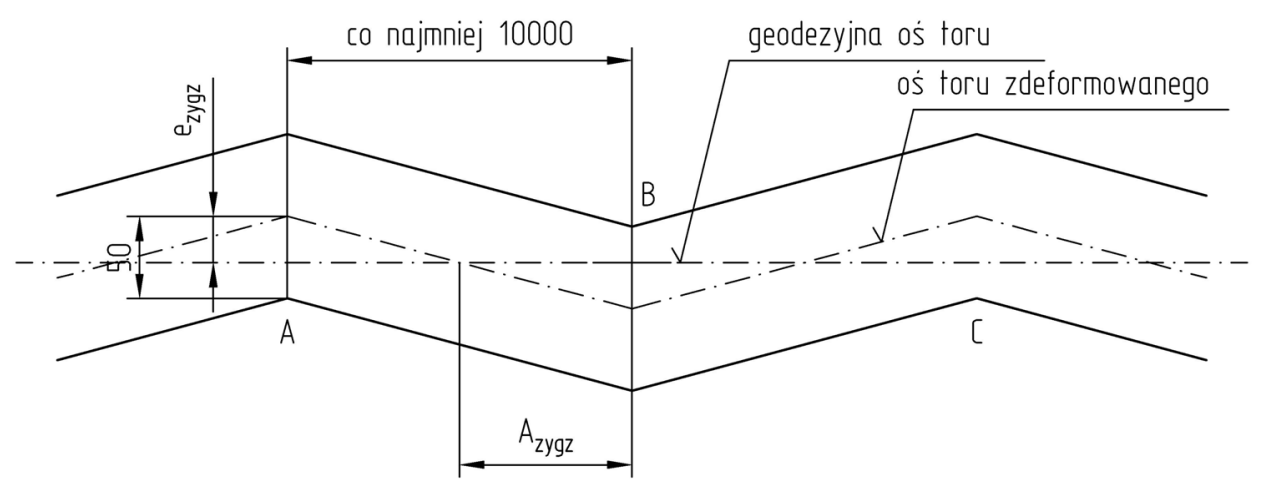

Rys. 1. Zygzakowatość toru 


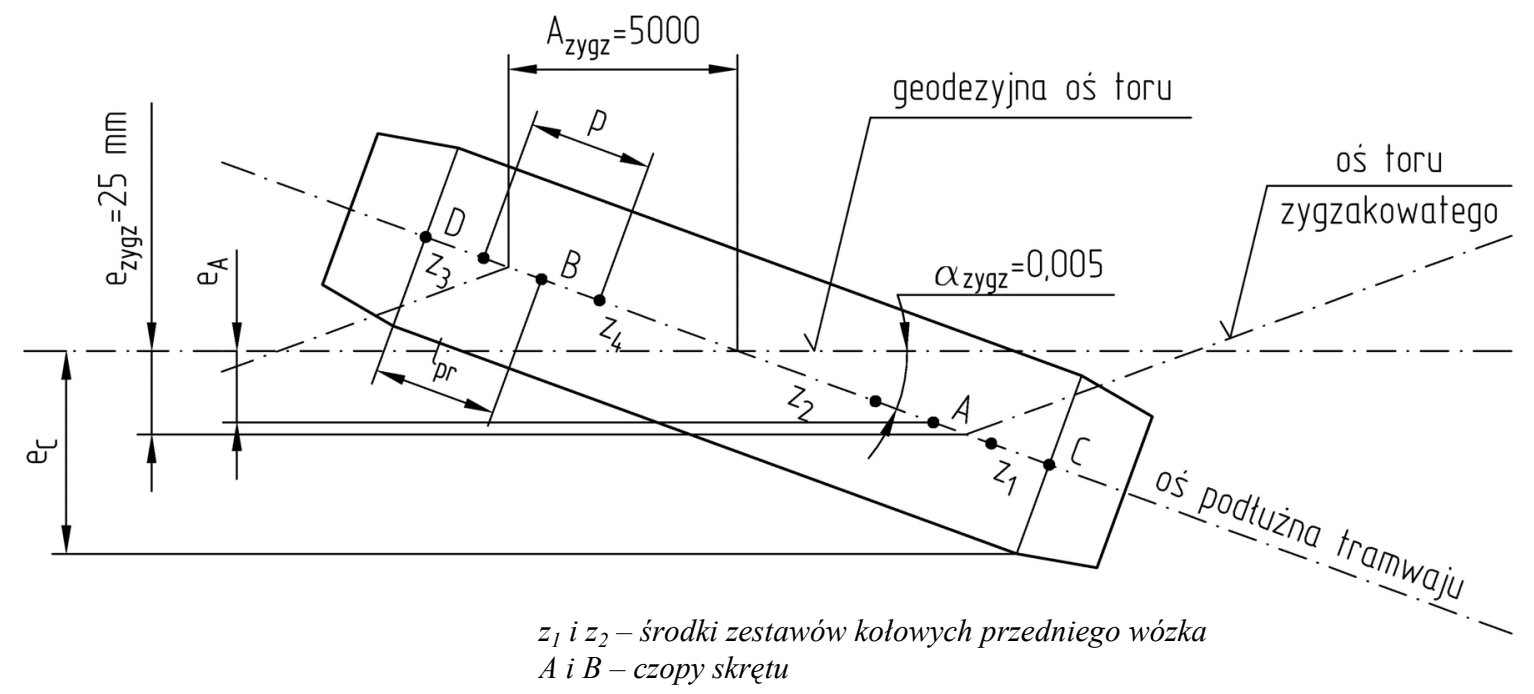

Rys. 2. Ustawienie pojazdu

Nie ma raczej szans na to aby kiedykolwiek wartość $\mathrm{p}$ mogła być mniejsza od obecnej 1,9m [1]. Z kolei wydaje się, że największa możliwa wartość $1_{\mathrm{pr}}$, jaka kiedykolwiek będzie mogła być zastosowana, nie będzie większa niż $3 \mathrm{~m}$. Przyjmując te wartości i podstawiając do $e_{c}$ otrzymamy

$\mathrm{e}_{\mathrm{c}}=\sim 35 \mathrm{~mm}$.

\section{Przesunięcie się toru w poprzek}

Dopuszczalne równoległe przesunięcie się toru w poprzek wynosi tak jak dopuszczalna zygzakowatość $[2,3]$

$\mathrm{e}_{\text {przes }}=25 \mathrm{~mm}=0,025 \mathrm{~m}$

\section{Nierównomierne zużycie boków szyn}

Według [2, 3] dopuszczalne zużycie boku szyny wynosi $15 \mathrm{~mm}$. Gdy boki szyny zużywają się jednakowo, to oś symetrii toru nie zmienia swego położenia i tor pozostaje idealny (rys. 3).

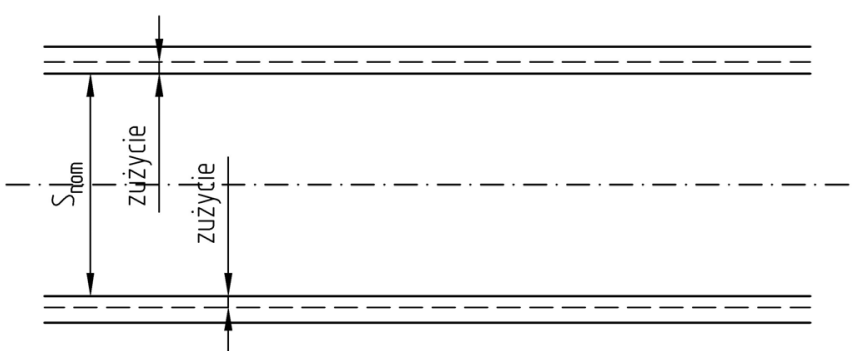

Taki przypadek rozpatrywano przy wyznaczaniu zarysu odniesienia skrajni kinematycznej.

Gdy tylko jedna szyna ulega zużyciu, to oś symetrii toru odbiega od swego początkowego położenia o połowę zużycia szyny (rys. 4).

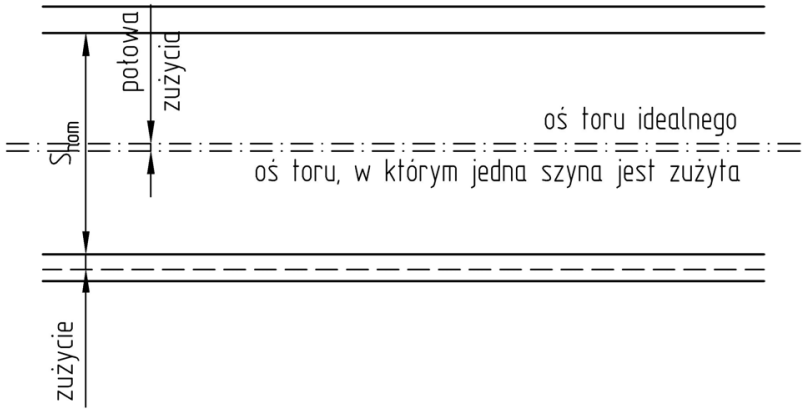

Rys. 4. Tor - niesymetryczne zużycie szyn

Zatem

$$
\mathrm{e}_{\mathrm{zuz}}=\frac{15}{2}=7,5 \mathrm{~mm}=0,0075 \mathrm{~m} .
$$

5. Jednoczesność zygzakowatości, przesunięcia równoleglego i zużycia boku pojedynczej szyny toru

$\mathrm{Na}$ torze zygzakowatym zawsze zużywają się boki szyn w punktach A, B i C (rys.1). Zatem zużywanie się szyn jak gdyby stara się „wyprostować” zygzakowatości. Wobec tego zygzakowatość jest najbardziej niekorzystna gdy zaistnieje na nowym niezużytym torze, co może nastapić na przykład w wyniku wysokiej temperatury latem.

Zatem przy zygzakowatości toru nie należy uwzględniać nierównomiernego zużywania się boków szyn.

Dla odmiany na torze przesuniętym w poprzek równolegle może wystąpić zużycie tylko jednej szyny i to dowolnej, czyli zużycie boku szyny może powiększyć przemieszczenie pasożytnicze (szkodliwe) pojazdu na przesuniętym torze. Łącznie przesunięcie wyniesie

Liczbowo wyniesie to

$$
\mathrm{e}_{\mathrm{p}}=\mathrm{e}_{\text {przes }}+\mathrm{e}_{\mathrm{zuz}}
$$

$$
e_{p}=25+7,5=32,5 \mathrm{~mm} \text {. }
$$


Tor nie może być jednocześnie zygzakowaty i przesunięty równolegle. Zatem zygzakowatość toru, dla której przesunięcie pasożytnicze pewnej części pojazdu w bok wynosi $e_{c}=35 \mathrm{~mm}$ jest przypadkiem bardziej niekorzystnym niż przesunięcie równoległe dające tylko $32,5 \mathrm{~mm}$ przemieszczenia pojazdu.

Wobec tego przemieszczenie pasożytnicze pojazdu wynikające $\mathrm{z}$ deformacji poziomych toru może wynosić

$$
\mathrm{e}_{\mathrm{poz}}=\mathrm{e}_{\mathrm{c}}=35 \mathrm{~mm} \text {. }
$$

\section{Zużycie główek szyn i zapadnięcie toru (rys. 5)} 6.1. Ustawienie statyczne pojazdu w zapadnięciu toru

Według [2, 3] dopuszczalne zużycie główki szyn wynosi $18 \mathrm{~mm}$, a dopuszczalne zapadnięcie toru 25 mm.

Przyjmiemy tę bardziej niekorzystną wartość $\mathrm{h}_{z a p}=25$ $\mathrm{mm}$. Im większa jest przy tym długość zapadnięcia, tym bardziej niekorzystna jest sytuacja dla skrajni. Jest nieprawdopodobne aby ta długość była większa niż $5000 \mathrm{~mm}$. Przyjmiemy tę wartość.

Opadnięcie pierwszego koła $\mathrm{K}_{1}$ wyniesie $\mathrm{h}_{\text {zap }}=25 \mathrm{~mm}$. Opadnięcie czopa skrętu wózka wyniesie

$$
\mathrm{h}_{\mathrm{cs}}=\mathrm{h}_{\mathrm{zap}}-\frac{\mathrm{p}}{2} \cdot \frac{\mathrm{h}_{\text {zap }}}{\mathrm{A}_{\text {zap }}}=\left(1-\frac{\mathrm{p}}{2 \mathrm{~A}_{\text {zap }}}\right) \mathrm{h}_{\text {zap }}
$$

Opadnięcie punktu C pudła pojazdu wynosi

$$
\mathrm{h}_{\mathrm{dó} \nmid}=\frac{\mathrm{a}+1_{\mathrm{pr}}}{\mathrm{a}} \cdot \mathrm{h}_{\mathrm{cs}}
$$

Podstawiając za $\mathrm{h}_{\mathrm{cs}}$ powyższą wartość otrzymamy

$$
\mathrm{h}_{\text {dół }}=\left(1+\frac{1_{\mathrm{pr}}}{\mathrm{a}}\right) \cdot\left(1-\frac{\mathrm{p}}{2 \mathrm{~A}_{\text {zap }}}\right) \cdot \mathrm{h}_{\text {zap }}
$$

Kontur koniecznej przestrzeni niezabudowanej musi być tak wyznaczony, żeby pasował do wszelkich typów tramwajów, nawet takich których obecnie jeszcze nie ma, ale które mogą być skonstruowane kiedyś w przyszłości. Wobec tego we wzorze (3) trzeba przyjąć największą możliwą wartość $1_{\mathrm{pr}}$, jaka kiedykolwiek może zostać zastosowana, najmniejszą możliwą wartość - a, najmniejszą możliwą wartość p i najmniejszą możliwą wartość $\mathrm{A}_{\text {zap }}$.

Obecnie na ogół a we wszystkich tramwajach na świecie wynosi około $6 \mathrm{~m}$. Nie widać powodów, dla których wartość ta mogłaby kiedykolwiek zostać zmniejszona ( raczej będzie występowała w przyszłości tendencja do zwiększenia wymiaru a).

Wobec tego przyjmiemy a $=6 \mathrm{~m}$.

Wydaje się, że największa wartość $1_{\mathrm{pr}}$ (odległość na zewnątrz czopa skrętu, na której będą wisiały na podwoziu niskozawieszone urządzenia), jaka kiedykolwiek zostanie zastosowana, nie będzie nigdy większa niż $3 \mathrm{~m}$ i tę wartość przyjmiemy.

Wartość p wynosi w obecnych tramwajach 1,9 m. Nie wydaje się możliwe zmniejszenie $\mathrm{w}$ przyszłości tej wartości, to też przyjmiemy $\mathrm{p}=1,9 \mathrm{~m}$.

Podstawiając powyższe dane do zależności (3) opadnięcie punktu $\mathrm{C}$ wyniesie $\mathrm{h}_{\mathrm{dó}}=\sim 30 \mathrm{~mm}$.

$\mathrm{Z}$ kolei punkt $\mathrm{D}$ pojazdu uniesie się $\mathrm{w}$ górę $\mathrm{o}$

$$
\mathrm{h}_{\text {góra }}=\frac{1_{\mathrm{pr}}}{\mathrm{a}} \cdot \mathrm{h}_{\mathrm{cs}}
$$

czyli

$$
\mathrm{h}_{\text {góra }}=\frac{1_{\mathrm{pr}}}{\mathrm{a}}\left(1-\frac{\mathrm{p}}{2 \mathrm{~A}_{\text {zap }}}\right) \cdot \mathrm{h}_{\mathrm{zap}}
$$

podstawiając dane otrzymamy $\mathrm{h}_{\text {góra }}=\sim 10 \mathrm{~mm}$.

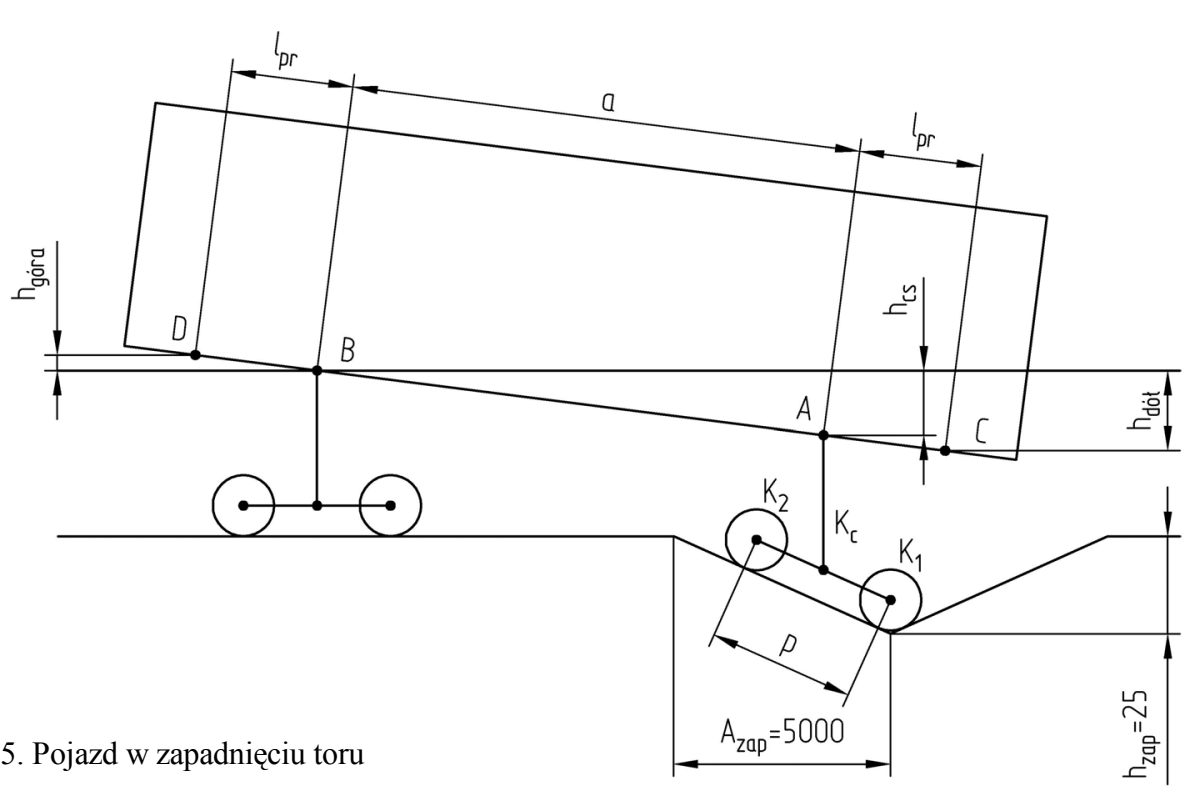


6.2.Ustawienie kinematyczne pojazdu w zapadnięciu toru

Ponieważ wyczerpanie wszystkich możliwych ugięć usprężynowania zostało już uwzględnione przy wyznaczaniu zarysu odniesienia skrajni kinematycznej, przeto powyżej wyznaczone wartości $h_{\text {góra }} \mathrm{i} h_{\text {dół sa }}$ jedynymi dodatkowymi przemieszczeniami pasożytniczymi tramwaju na zapadnięciu toru.

Zatem przemieszczenia pasożytnicze części pojazdu z tytułu deformacji pionowych toru wynosi:

- dla dolnych krawędzi pojazdu $h_{d o ́ t}=30 \mathrm{~mm}$

- dla górnych krawędzi pojazdu $h_{\text {góra }}=10 \mathrm{~mm}$.

\section{Wichrowatość toru}

\subsection{Dopuszczalna wichrowatość toru}

Dopuszczalna różnica poziomu obu szyn na torze prostym o szerokości $1435 \mathrm{~mm}$ wynosi $-\mathrm{W}=30 \mathrm{~mm}$, a dla toru o szerokości $1000 \mathrm{~mm}-\mathrm{W}=20 \mathrm{~mm}[2,3]$

Kąt poprzeczny wichrowatości toru

$$
\delta=\frac{\mathrm{W}}{\mathrm{S}_{\mathrm{t}}}
$$

Gdzie $\mathrm{S}_{\mathrm{t}}$-rozstaw kręgów tocznych zestawu kołowego

Dla toru $1435-\delta=\frac{30}{1500}=0,02$ a dla toru 1000 $\delta=\frac{20}{1065}=\sim 0,019$

W dalszych rozważaniach przyjmujemy jednolicie $\delta=$ 0,02 .

\subsection{Skutek geometrycznych wichrowatości toru}



Rys.6. Odchylenie pudła pojazdu
Odchylenie punktu A od płaszczyzny toru idealnego wynosi (rys.5)

$$
\mathrm{e}_{\text {geom wichr }}=\mathrm{h} \cdot \sin \delta=\sim \mathrm{h} \cdot \delta
$$

Temu jest też równe odchylenie punktu $\mathrm{B}$ od jego położenia na torze.

Analogicznie obniżenie się punktu $\mathrm{C}$ w stosunku do jego położenia na torze idealnym wynosi

$$
\mathrm{W}_{\text {geom wichr }}=\mathrm{b} \cdot \sin \delta=\sim \mathrm{b} \cdot \delta
$$

\subsection{Skutek statyczny wichrowatości toru}

$\mathrm{Na}$ torze wichrowatym na pojazd, choćby stojący nieruchomo, działa siła poprzeczna podobna do niezrównoważonej siły odśrodkowej działającej na łuku toru, gdy na tym łuku występuje niedobór lub nadmiar przechyłki (rys.7).

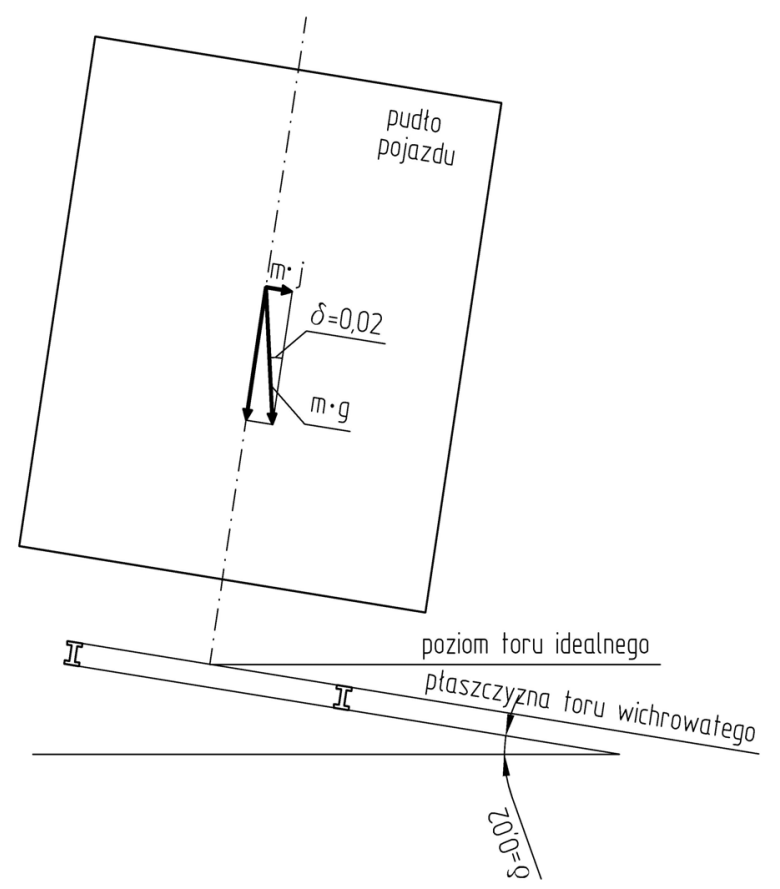

Rys. 7.Odchylenie pudła pojazdu - siła poprzeczna

$$
\text { Z rys. } 7 \text { wynika że, } \quad \frac{\mathrm{j}}{\mathrm{g}}=\sin \delta=\sim \delta
$$

gdzie $\mathrm{j}$ - przyspieszenie poziome

Pod wpływem siły poprzecznej równej m?j podparcie sprężyste pojazdu odkształca się a pojazd ulegnie dalszemu przechyleniu o kąt $\varepsilon$ (rys.8).

Kąt quasistatycznego przechylania pojazdu wywołany niezrównoważoną siła poprzeczną wynosi

$$
\varepsilon=\mathrm{s} \frac{\mathrm{j}}{\mathrm{g}}
$$

gdzie s-współczynnik przechylania pojazdu [1]

Wykorzystując zależność (7) mamy

$$
\varepsilon=s \cdot \delta
$$

Przyjęta wartość współczynnika s=0,4 [1] to

$$
\varepsilon=0,4 \cdot \delta
$$

Odchylenie punktu A od płaszczyzny symetrii toru wichrowatego może zatem wynieść 


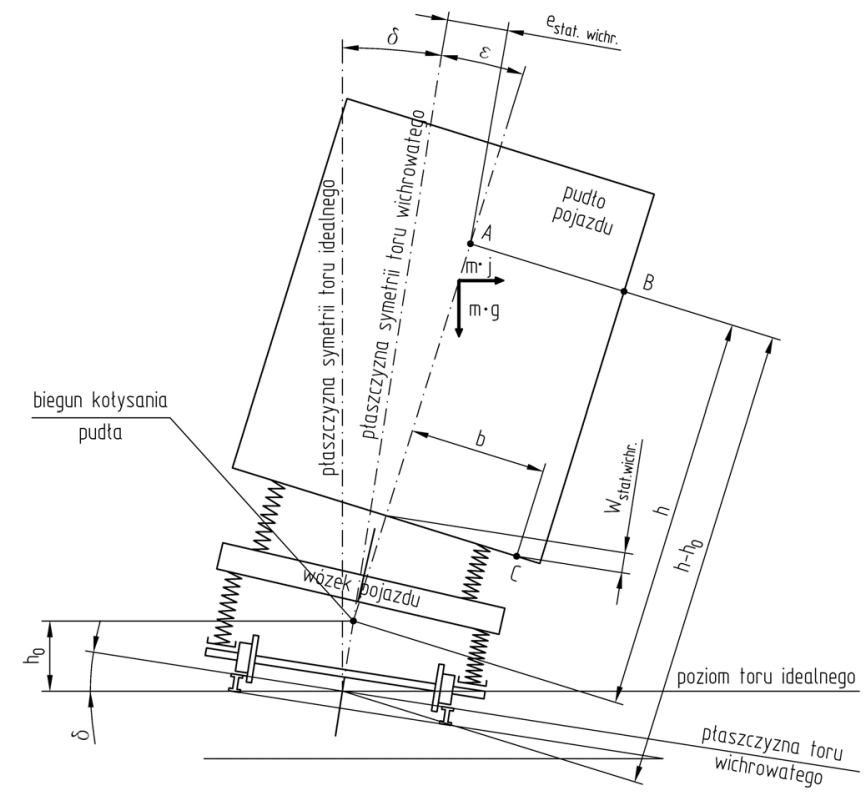

Rys.8.Przechylenie pojazdu

$\begin{array}{ll} & \mathrm{e}_{\text {stat wichr }}=\left|\mathrm{h}-\mathrm{h}_{0}\right| \cdot \sin \varepsilon=\sim\left|\mathrm{h}-\mathrm{h}_{0}\right| \cdot \varepsilon \\ \text { czyli } & \mathrm{e}_{\text {stat wichr }}=\left|\mathrm{h}-\mathrm{h}_{0}\right| \cdot \sin \varepsilon=\sim\left|\mathrm{h}-\mathrm{h}_{0}\right| \cdot 0,4 \cdot \delta\end{array}$

gdzie: h-wysokość rozpatrywanego punktu nad główkę szyny

$\mathrm{h}_{0}$-wysokość bieguna kołysania tramwaju nad główkę szyny

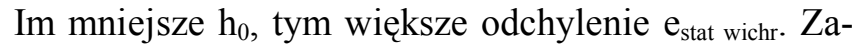
tem trzeba wziąć pod uwagę najmniejsze możliwe $h_{0}$. Jest nieprawdopodobne aby kiedykolwiek skonstruowano tramwaj o wysokości bieguna przechylania $h_{0}$ mniejszej niż $0,3 \mathrm{~m}$.

Zatem

$$
\mathrm{e}_{\text {stat wichr }}=|\mathrm{h}-0,3| \cdot 0,4 \cdot \delta
$$

Analogicznie obniżenie punktu $\mathrm{C}$ wyniesie

$$
\mathrm{W}_{\text {stat wichr }}=\mathrm{b} \cdot 0,4 \cdot \delta
$$

\subsection{Skutek dynamiczny wichrowatości toru}

Dynamicznym skutkiem wichrowatości toru jest kołysanie się pojazdu wokół bieguna kołysania, przy czym środkowym położeniem podczas tego kołysania jest położenie wywołane przez quasistatyczny skutek wichrowatości toru, określony w poprzednim punkcie.

Przyjmując współczynnik nadwyżki dynamicznej obciążenia poprzecznego $\mathrm{K}_{\mathrm{d}}=1,3$ taki sam, jaki przyjęto dla kołysania się tramwaju na torze idealnym [1], otrzymujemy amplitudę kołysania na wichrowatym torze równą

czyli

$$
\mathrm{e}_{\text {dyn wichr }}=\left(\mathrm{K}_{\mathrm{d}}-1\right) \cdot \mathrm{e}_{\text {stat wichr }}
$$

czyli

$$
\mathrm{e}_{\text {dyn wichr }}=\left(\mathrm{K}_{\mathrm{d}}-1\right) \cdot|\mathrm{h}-0,3| \cdot 0,4 \cdot \delta
$$

albo

$$
\mathrm{e}_{\text {dyn wichr }}=(1,3-1) \cdot|\mathrm{h}-0,3| \cdot 0,4 \cdot \delta
$$

Analogicznie będzie

$$
\mathrm{e}_{\text {dyn wichr }}=0,3 \cdot|\mathrm{h}-0,3| \cdot 0,4 \cdot \delta
$$

$$
\mathrm{w}_{\text {dyn wichr }}=0,3 \cdot \mathrm{b} \cdot 0,4 \cdot \delta
$$

7.5.Lączne przesunięcie pasożytnicze wynikające $z$ wichrowatości toru

czyli

$$
\mathrm{e}_{\text {wichr }}=\mathrm{e}_{\text {gem wichr }}+\mathrm{e}_{\text {stat wichr }}+\mathrm{e}_{\text {dyn wichr }}
$$

i ostatecznie

Analogicznie otrzymamy

$$
\mathrm{e}_{\mathrm{wichr}}=/ \mathrm{h}+0,52 \cdot|\mathrm{h}-0,3| / \cdot \delta
$$

czyli

$$
\mathrm{w}_{\text {wichr }}==/ \mathrm{b}+0,52 \cdot \mathrm{b} / \cdot \delta
$$

$$
\mathrm{w}_{\text {wichr }}==1,52 \cdot \mathrm{b} \cdot \delta
$$

Podstawiając tu $\delta=0,02$ otrzymamy

$$
\mathrm{e}_{\text {wichr }}=/ \mathrm{h}+0,52 \cdot|\mathrm{h}-0,3| / \cdot 0,02
$$

$\mathrm{W}_{\text {wichr }}=1,52 \cdot \mathrm{b} \cdot 0,02$

czyli

$$
\mathrm{w}_{\text {wichr }}=0,0304 \cdot \mathrm{b}
$$

Liczbowo wartości te wynoszą jak następuje:

- Na wysokości $h=3,2$ m

$\mathrm{e}_{\mathrm{wichr}}=(3,2+0,52 \cdot|3,2-0,3|) \cdot 0,02=(3,2+0,52 \cdot 2,9)$.

$\cdot 0,02=(3,2+1,503) \cdot 0,02=4,708 \cdot 0,02=0,09416 \mathrm{~m} \approx$ $94 \mathrm{~mm}$

- Na wysokości $\mathbf{h}=\mathbf{0 , 3} \mathbf{~ m}$

$$
\begin{aligned}
\mathrm{e}_{\mathrm{wichr}}= & (0,3+0,52 \cdot|0,3-0,3|) \cdot 0,02=(0,3+0,52 \cdot 0) \\
& \cdot 0,02=0,3 \cdot 0,02=0,006 \mathrm{~m}=6 \mathrm{~mm}
\end{aligned}
$$

\section{- Na wysokości h=0,060 m}

$\mathrm{e}_{\text {wichr }}=(0,060+0,52 \cdot \mid 0,060$ -

$$
\begin{aligned}
& 0,3 \mid) \cdot 0,02=(0,060+0,52 \cdot 0,24) \\
& \cdot 0,02=(0,08+0+0,1248) \\
& \cdot 0,02=0,1848 \cdot 0,02=0,003696 \mathrm{~m} \approx 4 \mathrm{~mm}
\end{aligned}
$$

$$
\begin{aligned}
& \text { - Na szerokości } \mathbf{b}=\mathbf{1 , 3 5} \mathbf{~ m} \\
& \mathrm{w}_{\mathrm{wichr}}=0,0304 \cdot 1,35=0,04104 \mathrm{~m} \approx 40 \mathrm{~mm}
\end{aligned}
$$

\section{Jednoczesność wichrowatości i zygzakowatości toru}

Wichrowatość i zygzakowatość toru mogą występować jednocześnie, ale prawdopodobieństwo tej jednoczesności jest takie, że można zastosować do niego prawa rozkładu zmiennych losowych.

Wypadkowe pasożytnicze ruchy poziome pojazdu wyniosą wtedy

- Na wysokości $h=3,2 \mathrm{~m}$

$$
\begin{aligned}
& \mathrm{D}=\sqrt{\mathrm{e}_{\text {wichr }}^{2}+\mathrm{e}_{\text {poz }}^{2}} \\
& \mathrm{D}=\sqrt{94^{2}+35^{2}}=\sim 100 \mathrm{~mm}
\end{aligned}
$$

- $\quad$ Na wysokości $h=0,3 \mathrm{~m}$

$$
\mathrm{D}=\sqrt{6^{2}+35^{2}}=\sqrt{36+1225}=\sim 36 \mathrm{~mm}
$$

- Na wysokości h=0,060 m

$$
\mathrm{D}=\sqrt{4^{2}+35^{2}}=\sqrt{16+1225}=\sim 35 \mathrm{~mm}
$$




\section{Jdnoczesność wichrowatości i zapadnięcia toru}

Wichrowatość i zapadnięcie toru wykluczają się nawzajem. Zatem wystarczy uwzględnić albo jedno albo drugie. Przy tym należy pamiętać o tym, że zarys odniesienia skrajni kinematycznej został opracowany w [1] w ten sposób, że ujmuje wszystkie pionowe ruchy pasożytnicze pojazdu na idealnym torze $\mathrm{w}$ takim rozmiarze, który wyczerpuje pionowe luzy elementów sprężystych do wyczerpania. Pojazd o wyczerpanych luzach pionowych nie może się kołysać, a zatem decydującym wymiarem jest przemieszczenie powstające przy zapadnięciu toru.

Zatem dla dolnej krawędzi skrajni, kiedy możliwość kolizji występuje przy dużych ugięciach resorów pojazdu, mamy

$$
\mathrm{W}=\mathrm{h}_{\mathrm{dó}}=30 \mathrm{~mm}
$$

Dla odmiany dla górnych krawędzi skrajni, kiedy możliwość kolizji występuje przy małych ugięciach resorów pojazdu mamy:

$$
\begin{aligned}
& \mathrm{W}=\mathrm{W}_{\text {wichr }} \\
& \text { co na szerkości } \mathrm{b}=1,35 \mathrm{~m} \text { wynosi } \\
& \mathrm{W}=40 \mathrm{~mm}
\end{aligned}
$$

\section{Dodatkowe przemieszczenia pasożytnicze pan- tografu}

Z uwagi na elastyczną konstrukcję pantografu można przyjąć, że na odkształceniach toru pantograf będzie starał się utrzymać poprzednie położenie nie ulegając dodatkowym ruchom pasożytniczym.

\section{Poszerzenie konturu koniecznej przestrzeni nie- zabudowanej na łukach}

Poszerzenie to jest identyczne jak poszerzenie zarysu odniesienia skrajni kinematycznej.

\section{Wnioski końcowe}

1. Kontur koniecznej przestrzeni niezabudowanej skrajni budowli omawiany w niniejszym opracowaniu ważny jest wtedy, gdy deformacje toru powstające w wyniku eksploatacji nie przekroczą następujących wartości:

- $\quad$ przesunięcie się osi podłużnej toru w poprzek mierzone od osi geodezyjnej toru $-25 \mathrm{~mm}$

- zygzakowatość toru (lub wielokątny kształt łuku toru) mierzony od osi geodezyjnej toru $25 \mathrm{~mm}$

- zapadnięcie się toru mierzone od poziomu geodezyjnego toru (włącznie z pionowym zużyciem główek szyn) $-25 \mathrm{~mm}$
- wichrowatość toru (niejednakowy poziom główek obu szyn) - $30 \mathrm{~mm}$ na torze o szerokości $1435 \mathrm{~mm}$, a $20 \mathrm{~mm}$ na torze o szerokości $1000 \mathrm{~mm}$.

Wszystkie powyższe deformacje mogą występować jednocześnie w tym samym punkcie toru, o ile ze swej natury same się nie wykluczaja wzajemnie (jak np. przesunięcie i zygzakowatość, albo zapadnięcie i wichrowatość).

2. Kontur koniecznej przestrzeni niezabudowanej skrajni budowli omawiany w niniejszym opracowaniu ważny jest wtedy, gdy po torze będa jeździły wagony tramwajowe, których cechy charakterystyczne będa następujące:

- wagon będzie kinematycznie zgodny z zarysem odniesienia skrajni kinematycznej (to znaczy w żadnym jego położeniu czy to na torze prostym, czy też na łuku toru żadna część wagonu nie będzie wystawać poza ten zarys odniesienia na idealnie niezdeformowanym torze zarówno w stanie spoczynku jak i w stanie jazdy $z$ prędkościami od 0 do maksymalnej i z uwzględnieniem maksymalnych amplitud wszelkich ruchów pasożytniczych wagonu spowodowanych prędkościami jazdy),

- prosta ściana boczna wagonu nie będzie wysięgała poza czop skrętu wózka o więcej niż $3 \mathrm{~m}$,

- na podwoziu nisko zawieszone części i mechanizmy nie będą rozmieszczone na długości większej niż $3 \mathrm{~m}$ mierzonej od czopa skrętu w kierunku do czoła lub tyłu wagonu,

- współczynnik przechylania wagonu s nie będzie większy niż 0,4 .

\section{Literatura}

[1] IPS „Wymiary dopuszczalne przekrojów wagonu tramwajowego $w$ świetle obowiazujacej skrajni kinematycznej." Nr OR-9130 opracowano $02.2007 r$.

[2] BN-89/9396-05/03: „,Komunikacja miejska. Skrajnia budowli." (Unieważniona 2.01.1998)

[3] PN-K-92009: styczeń 1998 „Komunikacja miejska -Skrajnia budowli-wymagania" 